\title{
THE COMPARISON OF USING MIND MAPPING AND KNOWLEDGE MAPPING TECHNIQUE TOWARD STUDENTS' READING COMPREHENSION IN REPORT TEXT AT THE ELEVENTH GRADE AT SMA N 1 TRIMURJO IN THE ACADEMIC YEAR 2015/2016
}

\author{
Defy Gustianing ${ }^{1}$, Hadiyan Muhammad Hariz ${ }^{2}$ \\ ${ }^{1}$ Ahmad Dahlan University of Yogyakarta - Indonesia \\ ${ }^{1}$ defygustianing@gmail.com \\ ${ }^{2}$ Ahmad Dahlan University of Yogyakarta - Indonesia
}

\begin{abstract}
The objectives of this research are to know whether there is a difference result of reading comprehension by using mind mapping and knowledge mapping technique or not and to know which one is more effective technique between mind mapping and knowledge mapping technique.This research is a quantitative research.The design of this research is pre test-post test control group design which employs two groups. Experimentgroup is treated by mind mapping technique and control class is treated by knowledge mapping technique. Then, the total population is 123 students at the eleventh grade of SMA N 1 Trimurjo. The researcher takes 40 students, 20 students as experiment and20 as control. In taking the sample, the researcher used total cluster random sampling.The result of $t_{\text {test }}$ is 2,91 and $t_{\text {table }}$ is 2,02 (on criterion 1) and 2,70 (on criterion 2). It means that $t_{\text {count }}>t_{\text {table. }}$. So, there is a difference result of reading comprehension by using mind mapping and knowledge mapping technique and reading comprehension by using mind mapping technique is more effective than knowledge mapping technique.
\end{abstract}

Keywords: mind mapping technique, knowledge mapping technique, reading comprehension, report text

\section{INTRODUCTION}

Reading is one of the skills has process of constructing meaning and information in written form. The information is written form which usually consist of text, article, advertisement and journal. So, it is needed to comprehend intensively. Comprehension is the ability to understand the content of text. Understanding can be translating meaning for each words or sentences, excavating information and language features that use in the text and analysis generic structure based on genre of text. From thus, it can help the reader to reap more knowledge about all shorts of informations which has useful in their society.

Reading is important for a variety of reasons. For example, it can be discover in learning and teaching especially for education field. In reading, it develops the mind. Teaching students to read helps them develop their language skills. It can be proven in instructional at school. This skill beside listening, speaking and writing that should be mastered by the students. Because of thus it makes them are able to comprehend the text and read the text intensly.

Depend on survey in June $4^{\text {th }} 2015$, the researcher observed teaching instructional in the class. Unfortunately, teaching and learning activities at school do not prompt them to do that. Skimming and pre-questioning technique in teaching reading at classroom has used. In fact, most of them do not have motivation and interest to follow instructional of reading's material in the class. It caused by condition of the class does not support the learning process. Finally, students are asked to read then answering the questions based on the text that has given to them. 
Afterward, the task submitted and never discuss it together. As a result, they never get feedback from teacher and their reading comprehension do not increase well. They get confuse to understand the materials and they got difficulties about the way to answer the questions based on the text. Based on the teaching and learning activities above, it can be concluded that students reading comprehension is low. Actually, the students are able to comprehend the text then answer the questions intensly but they are lazy to do so, whether the teacher have given clearly explanation. In this view, the students needed deep guidance for comprehensing the text.

From the description above, the researcher formulate the research objective are to know whether there is a difference result of reading comprehension by using mind mapping and knowledge mapping technique toward students' reading comprehension in report text at eleventh grade of SMAN 1 Trimurjo in the Academic Year of 2015/2016 or not and to know which one is more effective technique between mind mapping and knowledge mapping technique toward students' reading comprehension in report text at eleventh grade of SMAN 1 Trimurjo in the Academic Year of 2015/2016.

According to the introduction of this research the formulation of the problem are:

a. Is there any difference result of reading comprehension by using mind mapping and knowledge mapping technique toward students' reading comprehension in report text at the eleventh grade at SMAN 1 Trimurjo in the academic year of $2015 / 2016$ ?

b. Which one is more effective between mind mapping and knowledge mapping technique toward students' reading comprehension in report text at the eleventh grade of SMAN 1 Trimurjo in the academic year at 2015/2016?

In this research, the objectives of the research are:

a. To know whether there is a difference result of reading comprehension by using mind mapping and knowledge mapping technique toward students' reading comprehension in report text at eleventh grade at SMAN 1 Trimurjo in the academic year of 2015/2016 or not;

b. To know which one is more effective technique between mind mapping and knowledge mapping technique toward students' reading comprehension in report text at eleventh grade at SMAN 1 Trimurjo in the academic year of $2015 / 2016$

\section{LITERATURE REVIEW}

2.1 Concept of mind mapping

Toi (2009:8) states that mind mapping is the striking combination of imagery, colour and visual-spatial arrangement, which is proven to significantly improve information recall, compared to conventional methods of note taking and learning. It can help children recall words more effectively than using lists, with improvements in memory of up to $32 \%$.

According to Davies (2010:3) argues that "mind mapping has been defined as visual, non-linear representations of ideas and their relationships". Mind maps comprise a network of connected and related concepts. However, the idea can be connected to another. Spontaneous thinking is required when creating a mind map and the aim of mind mapping is to find creative associations between ideas. 
Below is the eaxample of mind mapping in report text;

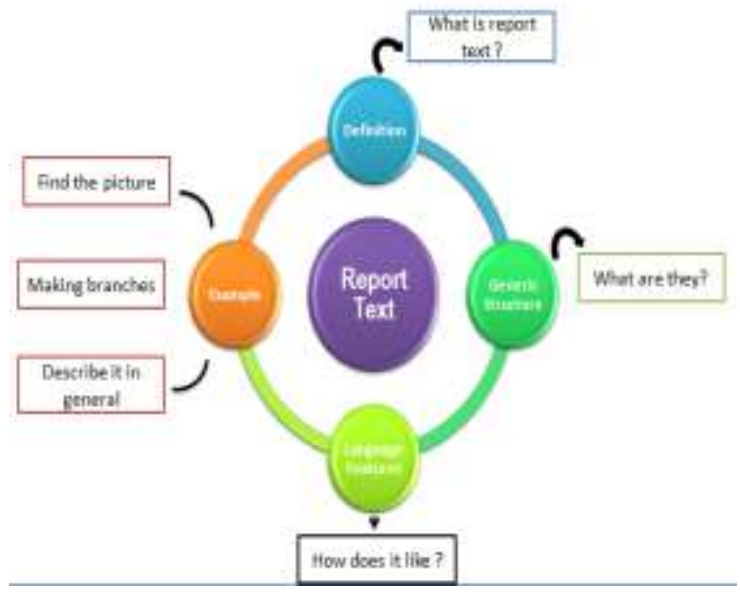

(Source: The Researcher)

From the description above, it has connection with reading comprehension. Using mind mapping in learning text produce a lot of information. It helps the students to cope with complex text by using branch in map. It needs intensive imagination when the learners want to highlight the information in each paragraph.

2.2 Concept of Knowledge Mapping technique

Balaid (2012:62) states that "knowledge mapping gives a holistic overview of knowledge resources". Knowledge mapping is one of the most popular techniques used to identify knowledge in organizations. Using knowledge mapping techniques in a large and complex set of knowledge resources can be acquired and navigated more easily. Knowledge mapping has attracted the senior managers' attention as an assessment tool in recent years and it is expected to measure deep conceptual understanding and allow experts in organizations to characterize relationships between concepts within a domain visually.

Table 1. Objects Map

\begin{tabular}{|l|l|}
\hline \multicolumn{1}{|c|}{ Type of Knowledge } & \multicolumn{1}{c|}{ Objects } \\
\hline $\begin{array}{l}\text { Explicit Knowledge } \\
\text { (stating the phenomenon clearly) }\end{array}$ & $\begin{array}{l}\text { Subject, Purpose, Location, Format, Ownership, } \\
\text { User }\end{array}$ \\
\hline $\begin{array}{l}\text { Tacit Knowledge } \\
\text { (telling general aspect in view of the object) }\end{array}$ & Expertise, Accessibility \\
\hline $\begin{array}{l}\text { Tacit organizational Process Knowledge } \\
\text { (understanding about the object in item) }\end{array}$ & $\begin{array}{l}\text { Something with the internal processing } \\
\text { knowledge }\end{array}$ \\
\hline $\begin{array}{l}\text { Explicit Organizational Process Knowledge } \\
\text { (describing the thing which will be discussed in } \\
\text { detail or part) }\end{array}$ & Codified organzational process knowledge \\
\hline
\end{tabular}

Source : Balaid (2014:62)

Jafari (2009:1) states that process knowledge mapping is a method of analysis to define the knowledge needed and the knowledge available to support a process. So it needs steps for building knowledge map in learning, the steps as follows;

1. Students should identify the requirements.

2. Students conducts information sources to use.

3. Students creates the map in summary.

4. Students select the object that can be mapped based on the components. 


\subsection{Concept of reading comprehension}

According to Harmer (2007:101) states that "reading for detailed comprehension, whether this entails looking for detailed information or picking out particular examples of language use, should be seen by students as something very different from the skills mentioned above". Many students are perfectly capable of doing all these things in other languages, of course, though some may not read much at all in their daily lives. For both types of student, we should do our best to offer a mixture of materials and activities so that they can practise using these various skills with English text.

Meanwhile as Miller (2010:170) states that "reading comprehension ability is the ability to construct meaning from a given written text". Reading comprehension is not a static competency; it varies according to the purpose for reading and the text that is involved. While, A reading expert, Maria in Arieta (2005:2) defines reading comprehension as holistic process of constructing meaning from written text through the interaction of;

1) The knowledge the reader brings to the text, include of word recognition ability, world knowledge, and knowledge of linguistic conventions;

2) The reader's interpretation of the language that the writer used in constructing the text; and

3) The situation in which the text is read. Based on some definitions above, it can be inferred that reading comprehension is a process of constructing a meaning from a written text that involves the interaction of the the reader's prior knowledge with the new given information.

Based on the description above, reading comprehension can be concluded as an understanding the content of the text. It is needed for the students to have a good ability to comprehend the textbook in order to gain the useful information from what has been read.

\subsection{Concept of report text}

According to Turmudi (2013:11) states that "report is a text which represent information about something, as it is". It is as a result of systematic observation and analysis. Interpretation of the reporter is mostly avoided. As while, based on Doddy (2008:23) conclude that "Report text is a kind of text which has social function to describe the way things are, with the reference to a range of natural, man made and social phenomena in our environment".

It has generic structure of report text, they aregeneral classification and description. General classification, tells what the phenomenon under discussion is and description tells what the phenomenon under discussionis like in item of behaviour. Not only that, but also it has language features. The features are introducing group or general aspect, using conditional logical connection, using simple present tense.

From thus, it can be concluded that report text is one of the genre of text that should be comprehended by students. Just because it can help students know or excavate information of the text generally based on things which describe it in text.

\section{METHODS}

The researcher starts her research by making the planning. The planning is named as research design. This research is quantitative research. Research design that is used in this research is quasi experimental design. The research carries out in SMA N 1 Trimurjo at the eleventh grade in the academic year 2015/2016. The kind of design is pretest-posttest control group design. The design can be seen below: 
Table 2. Pretest - Posttest Control Group Design

\begin{tabular}{|c|c|c|c|}
\hline Group & Pre Test & Treatment & Post Test \\
\hline $\begin{array}{c}(\mathrm{M})(\mathrm{R}) \\
\text { Experiment }\end{array}$ & $\mathrm{T}_{1}$ & $\mathrm{X}_{1}$ & $\mathrm{~T}_{2}$ \\
\hline $\begin{array}{c}\mathrm{M})(\mathrm{R}) \\
\text { Control }\end{array}$ & $\mathrm{T}_{1}$ & $\mathrm{X}_{2}$ & $\mathrm{~T}_{2}$ \\
\hline
\end{tabular}

Source : Adopted from Sugiyono (2012:112)

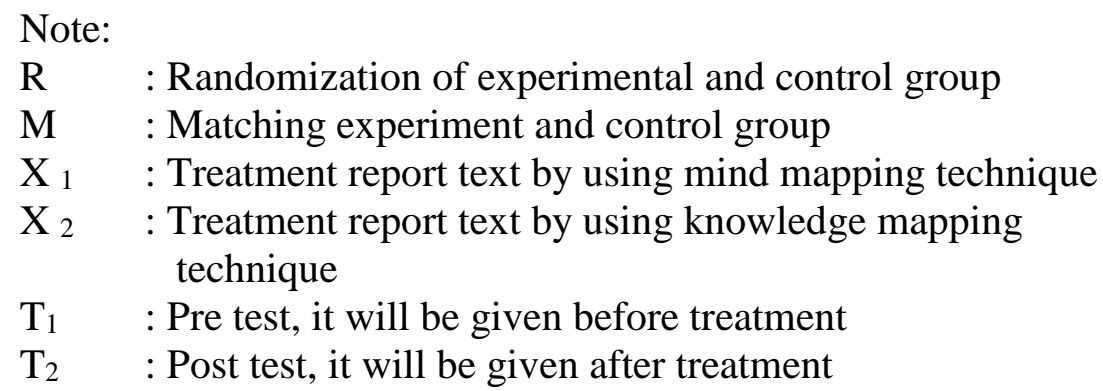

Based on the table above, the researcher takes the popoulation of the research is students at eleventh grade of SMA N 1 Trimurjo. The total of population are 123 students. Where as this research deals with two classes. The researcher takes sample from XI IPS 1 have 20 students that consist of 8 male and 12 female and XI IPS 2 have 20 students that consist 8 male and 12 female. The classes chosen in randomization that has same capability by using cluster random sampling technique.

Each of classes receive pre-test, treatment and post-test. Conducting pre test for knowing the class equivalent or not and to diagnose the students' prior ability in reading report text. It conducts before the teacher give the treatments. Pre-test instrument is in a multiple choice form and it has fifteen questions focusing on looking for explicity information from the text after they learn about description of things by using mind map. The treatment conducts for about three weeks. Furthermore, experiment class is instructed by using mind mapping technique. While control class is instructed by using knowledge mapping technique for reaping the information or point of view that contain in text intensively. It has function for knowing how far students' master in reading especially comprehend the text. The last is conducting post test, the purpose is to find out whether the use of mind mapping technique makes impact for their reading comprehension or not. Then it will be compare with the result of knowledge mapping technique to know which one more effective for learning report text. The post-test is in a multiple choice form and it consists of fifteen questions.

In analysing the data, the researcher use the result of post test in experiment and control class. The data analysis that use by researcher are normality, homogenity, and hypothesis. For analyzing normality test, the researcher use liliefors formula. As while analyzing homogenity test, the researcher use F-test. In line, analysing hypothesis test the researcher use t-test two sample.

\section{FINDINGS AND DISCUSSION}

The result of the research is including normality test, homogenity test and hypothesis of experiment class and control class. First, the result of normality test. The main point in computing normality is to find out whether the data was distributed normal or not. The data is in the normal distribution or accepted Ho if 
$\mathrm{X}^{2}$ hit $\leq \mathrm{X}^{2}$ daf for the significant level is $5 \%(\alpha=0.05)$ and also the significant level $1 \%(\alpha=0.01)$.

Table 3. The Data Result of Normality Distribution

\begin{tabular}{|c|l|l|l|l|l|l|}
\hline Variable & $\mathbf{X}$ & \multicolumn{1}{|c|}{ SD } & L-ratio & $\begin{array}{c}\text { L-table } \\
(\mathbf{0 , 0 5})\end{array}$ & $\begin{array}{c}\text { L-table } \\
(\mathbf{0 , 0 1})\end{array}$ & Conclusion \\
\hline $\mathrm{X}_{1}$ & 85,4 & 4,49 & 0,181 & 0,190 & 0,231 & Normal \\
\hline $\mathrm{X}_{2}$ & 80,4 & 6,34 & 0,145 & 0,190 & 0,231 & Normal \\
\hline
\end{tabular}

Source: The result of normality test in experimental and control clas

Notes :

$\mathrm{X}_{1} \quad$ : Experiment Class

$\mathrm{X}_{2} \quad$ : Control Class

$\mathrm{X}$ : Average

SD : Standard Deviation

From the data result above, it was obtained that $\mathrm{X}^{2}$ hit $\left(\mathrm{L}_{\text {-ratio }}\right)$ post-test was lowest than $X_{\text {daf }}^{2}\left(\mathrm{~L}_{\text {table }}\right)$ in both of the significant level $5 \%(\alpha=0.05)$ and $1 \%$ $(\alpha=0.01)$. Thus, it was implied that the data distribution test was normal.

After analyzing the normality of sample distribution, then the researcher analyze the homogeneity of the data. Homogeneity needed to determine the data variety. The data result of homogeneity test accepted $\left(\mathrm{H}_{\mathrm{a}}\right)$ if $\mathrm{F}_{\text {table }} \leq \mathrm{F}_{\mathrm{daf}}$ for the significant level of $10 \%(\alpha=0.05)$ and $2 \%(\alpha=0.01)$.

Tabel 4. The Data Result of Homogeneity Test

\begin{tabular}{|c|l|l|l|l|l|l|}
\hline Variable & \multicolumn{1}{|c|}{$\mathbf{X}$} & \multicolumn{1}{|c|}{$\mathbf{S}^{\mathbf{2}}$} & \multicolumn{1}{|c|}{ F-ratio } & $\begin{array}{c}\text { F-table } \\
(\mathbf{0 , 0 5})\end{array}$ & $\begin{array}{c}\text { F-table } \\
(\mathbf{0 , 0 1})\end{array}$ & Conclusion \\
\hline $\mathrm{X}_{1}$ & 85,4 & 20,14 & 0,55 & 2,15 & 3,00 & Homogeneous \\
\hline $\mathrm{X}_{2}$ & 80,4 & 40,14 & & & & \\
\hline
\end{tabular}

Source : the result of homogeneous post-test in experment and control class

From the data result above, the result was homogeneous; the post-test showed $F_{\text {ratio }}$ was 0,55 . In significant level 0,05 or $0,01 F_{\text {ratio }}<F_{\text {tab. So, }} \mathrm{H}_{0}$ accepted or in other word both sample of the population have same variance or homogeneous.

The last analysing is hypothesis.

4.1 Testing Hypothesis 1 (Assuming Equal Test)

1) Hypothesis

a) $\mathrm{H}_{0}: \mu_{1}=\mu_{2}$

There is no difference result of reading comprehension by using mind mapping and knowledge mapping technique toward students' reading comprehension in report text at the eleventh grade of SMAN 1 Trimurjo in the academic year of 2015/2016.

b) $\mathrm{H}_{\mathrm{a}}: \mu_{1} \neq \mu_{2}$

There is a difference result of reading comprehension by using mind mapping and knowledge mapping technique toward students' reading comprehension at the eleventh grade of SMAN 1 Trimurjo in the academic year of 2015/2016 
2) Statistic Hypothesis

$\mathrm{H}_{\mathrm{o}}$ is rejected if $\mathrm{t}_{\text {count }}>\mathrm{t}_{\text {table }}$

On significance level $(\alpha)=5 \%$, gotten:

$$
\begin{aligned}
t_{\text {daf }} & =t_{\left(1-\frac{1}{2} \alpha\right),\left(n_{1}+n_{2}-2\right)} \\
& =t_{(0,975) .(38)} \\
& =2,02
\end{aligned}
$$

Based on the data analyzing the data, it is found that $t_{\text {count }}=2,91$ and $t_{\text {table }}=2,02$. So, $H_{o}$ is rejected and $H_{a}$ is accepted. It means that there is a difference result of reading comprehension by using mind mapping and knowledge mapping technique toward students' reading comprehension in report text at eleventh grade of SMAN 1 Trimurjo in the academic year of 2015/2016.

4.2 Testing Hypothesis 2 (Assuming Unequal Test)

1) Hypothesis

a) $\mathrm{H}_{0}: \mu_{1} \leq \mu_{2}$

Reading comprehension by using mind mapping is not effective or same than knowledge mapping technique toward students' reading comprehension in report text at the eleventh grade of SMAN 1 Trimurjo in the academic year of 2015/2016.

b) $\mathrm{H}_{\mathrm{a}}: \mu_{1}>\mu_{2}$

Reading Comprehension by using mind mapping is more effective than knowledge mapping technique toward students' reading comprehension in report text at the eleventh grade of SMAN 1 Trimurjo in the academic year of 2015/2016.

2) Statistic Hypothesis :

$\mathrm{H}_{\mathrm{o}}$ is rejected if $\mathrm{t}_{\text {count }}>\mathrm{t}_{\text {table }}$

On significance level $(\alpha)=1 \%$, gotten:

$$
\begin{aligned}
t_{\text {daf }} & =t_{\left(1-\frac{1}{2} \alpha\right),\left(n_{1}+n_{2}-2\right)} \\
& =t_{(0,975) .(38)} \\
& =2,70
\end{aligned}
$$

The result finds that $t_{\text {count }}=2,91$, moreover the researcher looks at $t_{\text {table }}$ for $\alpha=1 \%$, the $t_{\text {table }}=2.70$. It means $t_{\text {count }}>t_{\text {table. }}$ So, Ho is rejected and $\mathrm{Ha}$ is accepted. It means that reading comprehension in report text by using mind mapping is higher than by using knowledge mapping technique at the eleventh grade at SMAN 1 Trimurjo in the academic year of 2015/2016.

Based on the description above and the result of criteria of the hypothesis on the table above, it is obtained that $\mathrm{H}_{\mathrm{a}}$ is accepted while $\mathrm{H}_{0}$ is rejected. It means that there is a difference result of reading comprehension by using mind mapping and knowledge mapping technique toward students' reading comprehension in report text at the eleventh grade at SMAN 1 Trimurjo in the academic year of 2015/2016. It also can be said that reading comprehension byusing mind mapping is more effective than knowledge mapping technique toward students' reading comprehension in report text at the eleventh grade at SMAN 1 Trimurjo in the academic year of 2015/2016.

This research has purpose to know whether there is a difference result of reading comprehension by using mind mapping and knowledge mapping technique toward students' reading comprehension in report text at the eleventh grade of 
SMAN 1 Trimurjo in the academic year of 2015/2016 and to know which one is more effective technique between mind mapping and knowledge mapping technique toward students' reading comprehension in report text at eleventh grade of SMAN 1 Trimurjo in the academic year of 2015/2016. The researcher gave the pre-test, treatments and post-test to the students as the sample of the research. The researcher describes the finding of the research as the result of data hypothesis as follows;

a. There is a difference result of reading comprehension by using mind mapping and knowledge mapping technique toward students' reading comprehension in report text

According to Harmer (2007:283) states that "reading comprehension means making sense of what you read and connecting the ideas in the text to what you already know". Moreover explanation about reading comprehension is as a complex intellectual process involving a number of abilities. The using of mind mapping will increase student's reading comprehension, because they will be motivated and have the first expectation about the text. As Dock (2000:48) states that the description of mind mapping is to manage the information and thinking imaginary. In this case students underline the main topic or issue in the centre of a large paper by using branches, then students draw sub branches in order to highlight ideas connected to the main branch. From thus, it can help the students easy to find out main idea, supporting sentences or description in text by answer the questions that provided.

Whereas, the using of knowledge mapping technique will helps the students to develop main ideas' contents of the text by understanding process without read the text in detail. As Jafari (2009:1) states that process knowledge mapping is a method of analysis to define the knowledge needed and the knowledge available to support a process. So it needs steps for building knowledge map in learning. In line, students are given worksheet by the teacher then analyse and describe the picture in detail based on aspect of view in a paragraph. Not only those, but also students manage the list of description based on the picture.

Even though, both of the techniques have similarity but in each technique has different advantages. From both technique applied in learning strategies, then the researcher find out the calculation score for each classes. It showed that there are some different results between pre-test and post-test score in experiment and control class.

b. Reading comprehension byusing mind mapping is more effective than knowledge mapping technique toward students' reading comprehension in report text

Toi (2009:8) states that mind mapping is the striking combination of imagery, colour and visual-spatial arrangement, which is proven to significantly improve information recall, compared to conventional methods of note taking and learning. Meanwhile Watthananon (2012:32) says that "Knowledge map shows relations among procedures, concepts and competency and provides easy and effective access to knowledge sources". In line, Balaid (2012:62) states from his journal that "knowledge mapping gives a holistic overview of knowledge resources". The experts above argue in each teachniques in order to teaching technique used will give more contribution to the students. It is happen because the students have high interest. If the technique use does not connect with students feeling, it will be there is no significant progress. In line in the previous research by Dona (2014) The 
Comparison of Students' Writing Ability of Hortatory Exposition Text Using Mind Mapping and Peer Editing Technique at The Eleventh Grade of SMA N 2 Metro Academic Year 2013/2014, Mind mapping technique is better than peer editing technique toward writing ability in hortatory exposition test at the eleventh grade of SMA N 2 Metro.

From the description above, in this research reading comprehension by using mind mapping technique and knowledge mapping technique are different, because they have different type and rule. From the discusions above, the researcher knows that there is a difference result of reading comprehension by using mind mapping and knowledge mapping technique toward students' reading comprehension in report text. Then, reading comprehension by using mind mapping technique is more effective than knowledge mapping technique for managing comprehension in reading skill. As a result, mind mapping can help the students to highlight main idea in each paragraph by using branches that they make when they are reading the text. Not only to highlight the main idea, but also it can increase studeents' skill in develop their mind to underlined the supporting sentences in each paragraph.

\section{CONCLUSION AND SUGGESTION}

After the researcher finished the research and analyzed the data, the she conclude that based on theoritical and result of data analysis. From her research entitled "The Comparison of Using Mind Mapping and Knowledge Mapping Technique towards Students' Reading Comprehension in Report Text at the Eleventh Grade of SMA N 1 Trimurjo in academic year 2015/2016", it can be conclude that there is a difference result of reading comprehension by using mind mapping and knowledge mapping technique toward students reading comprehension in report text at eleventh grade of SMAN 1 Trimurjo in the Academic Year of 2015/2016, then reading comprehension in report text by using mind mapping is more effective than knowledge mapping technique toward students' reading comprehension in report text at eleventh grade of SMAN 1 Trimurjo in the Academic Year of 2015/2016. The conclusion above can be shown based on the findings of data analysis as follows;

1) From data analysis, there is a difference result of reading comprehension by using mind mapping and knowledge mapping technique toward sudents reading comprehension in report text at the eleventh grade at SMAN 1 Trimurjo in the academic year of $2015 / 2016$. It is proved that based on the result of $t_{\text {test, }}$, where $t_{\text {count }}=2,91$ is higher than $t_{\text {table }}=2,02$ on the criteria 0,05 . It means that the students' reading comprehension will be increase if the teacher uses mind mapping technique in learning activities. Therefore, the researcher conclude that are different result of reading comprehension by using mind mapping and knowledge mapping technique toward students' reading comprehension in report text at the eleventh grade of SMA N 1 Trimurjo in academic year 2015/2016.

2) Reading comprehension by using mind mapping technique is more effective than knowledge mapping technique students' reading comprehension in report text at the eleventh grade at SMA N 1 Trimurjo in the academic year $2015 / 2016$. It can be seen from the result of of $t_{\text {test, }}$,where $t_{\text {count }}=2,91$ is higher than $t_{\text {table }}=2,70$ on the criteria 0,01 and the average score of the students were taught by using mind mapping is higher han knowledge mapping technique. Therefore, it is clearly seen that the hypothesis $\mathrm{H}_{0}$ is rejected and $\mathrm{H}_{\mathrm{a}}$ is accepted. 
Based on the result and the discussion above, the researcher concludes that there there is a difference result of reading comprehension by using mind mapping and knowledge mapping technique toward students' reading comprehension in report text at eleventh grade of SMAN 1 Trimurjo in the academic year of $2015 / 2016$ and reading comprehension byusing mind mapping is more effective than knowledge mapping technique toward students' reading comprehension in report text at eleventh grade of SMAN 1 Trimurjo in the academic year of 2015/2016.

After the researcher makes the conclusion of the result of reading comprehension by usingmind mapping and knowledge mapping technique toward students' reading comprehension in report text at the eleventh grade at SMA N 1 Trimurjo in academic year 2015/2016. The researcher would gave show some suggestion for the teachers, the students and for the other researchers.

1) For the teachers

To make the students become easy in reading comprehension, the teacher should use suitable technique for that. The using of learning technique and media in the class is very important to help students in understanding the material. For example the using mind mapping and knowledge mapping technique in teaching reading. In other side, the teacher should make combination of learning techniques in order to make students more interest to study. The teacher may not use same technique in some meetings, because it will make the students feel bored. Learning activity which will be held by teacher determine the students' result.

Besides students' reading comprehension improves, the teacher should consider the weaknesses of applying the mind mapping and knowledge mapping because it cannot be used in too big class. If it happens, the teacher should provide more than one topics. Then, the teacher should give more attention to supervise all groups in the class at the same time.

2) For the students

The students who learn English, especially reading must enhance their learning interest to learn and involve in the teaching-learning process actively. After getting some new text, students are expected not only to be able to comprehend the text but also to produce them in a context.

In learning reading, students are also expected to learn independently outside the class by having some student centered strategies. By this way, they can improve their knowledge to develop the idea in text and find main idea in text.

3) For the other research and researcher

Since this research had been finished and got the data conclusion about the comparison ofstudents' reading comprehension using mind mapping and knowledge mapping technique at the eleventh grade. Researcher expects for other researcher to understand well about this research in order to make easy for doing further research.

\section{REFERENCES}

Arieta C. 2010. Reading Comprehension Overview. The Landmark College Guide. Ed, 1-5. Retrievied January, 102016 from http://Arieta.edu/ Reading to English Language Learners: A Reflective Guide /.

Balaid, Ali Saleh S. 2014. A Comprehensive Review of Knowledge Mapping Technique. Journal of Computing Research. 62.

Brown, Douglas. 2001. Teaching by Principle. San Francisco: Addison Wesley Longman, Inc. 
Djamal, Murni., et al. 2006. Improving reading skill in English. Jakarta, Kencana Prenada Media Group.

Dock, Clarendon. 2007. Active learning and teaching methods for key stages $1 \& 2$.Northern Ireland Curriculum : CCEA, 29.

Doddy, Ahmad., et al. 2008. Developing English Competencies. Jakarta : Pusat Perbukuan Departemen Pendidikan Nasional.

Harmer, Jeremy. 2007. The Practice of English Language Teaching. Edinburg Gate England: Pearson Longman.

Jafari, Mostafa. (et. al.) 2009. A Framework For The Selection of Knowledge Mapping Techniques. Journal of Knowledge Management Practice. Vol. 10, No. 1.

Miller, Debbie. 2010. Reading with Meaning, Teaching Comprehension in the Primary Grades. England:Stenhouse Publisher.

Toi, H. 2009. Research on how Mind Map improves Memory. Paper presented at the International Conference on Thinking. 1-72.

Turmudi, Dedi. 2013. Smart and Skilfull Writer, Steps to developing your live writing skill 2. Metro: UMM Press.

Watthananon, J. 2012. Optimizing Knowledge Management using Knowledge Map. American Educational Research. 32. 